\title{
Środki wolnościowe w systemie readaptacji społecznej
}

\author{
Magdalena NiEWIAdOMSKA-KraWCZYK \\ ORCID: 0000-0002-7070-8616 \\ Katedra Prawa Karnego Wykonawczego \\ Uniwersytetu Łódzkiego
}

Podejmowany w niniejszym opracowaniu temat dotyczy bardzo ważnej, ale też niezwykle skomplikowanej materii, jaką jest zagadnienie readaptacji społecznej, a konkretnie roli, jaką mogą bądź powinny odgrywać w niej środki wolnościowe.

Ze względu na mnogość poruszanych kwestii należy dokonać pewnego uporządkowania terminologicznego. Przede wszystkim trzeba odnieść się do pojęcia „readaptacja społeczna”. Zgodnie z definicją słownikową „readaptacja” to „ponowne przystosowanie człowieka (chorego, niepełnosprawnego) do czynnego, samodzielnego życia w społeczeństwie i do pracy zawodowej"1.

W literaturze wskazuje się, że jest to „proces, którego istotą jest ponowne przystosowanie się do społeczeństwa, do obowiązujących w nim standardów społecznych", , jak również ,ponowne przystosowanie się jednostki do czynnego i samodzielnego życia, wyrażającego się w pełnieniu

1 Słownik języka polskiego PWN, www.sjp.pwn.pl (dostęp: 1.03.2020).

2 H. Machel, Dewiacyjna tożsamość grupowa skazanych a ich readaptacja i reintegracja społeczna, [w:] Tożsamość grupowa dewiantów a ich reintegracja społeczna, red. W. Ambrozik, A. Kieszkowska, Kraków 2012, s. 42-43. 
ról społecznych związanych z podstawowymi sferami i płaszczyznami ludzkiej egzystencji" ". Choć nie wypracowano jednolitej definicji omawianego pojęcia, przyjmuje się, że ,jest to proces, który rozpoczyna się już w warunkach instytucji resocjalizacyjnej, a jego finalnym etapem jest reintegracja, która stanowi ponowną integrację człowieka ze światem społecznym, następującą po okresie przeżyć traumatycznych, zachwiania zdrowia psychicznego lub izolacji'^4.

Dodać należy, że dotyczy on dwóch grup: pierwsza to osoby, które w procesie socjalizacji nie nabyły zdolności adaptacyjnych, druga zaś to osoby, które z różnych względów takie zdolności utraciły ${ }^{5}$. W tym drugim przypadku chodzi głównie o powrót do życia społecznego osób okresowo wyizolowanych z naturalnego życia społecznego, czyli tak zwaną readaptację penitencjarną — która następuje po opuszczeniu zakładu karnego przez skazanych na karę pozbawienia wolności, którzy najpierw zostali poddani procesowi resocjalizacji w warunkach izolacji. Takie ujęcie readaptacji społecznej jako etapu następującego po opuszczeniu zakładu karnego, którego zadaniem jest kontynuacja procesu resocjalizacji, skłania do ustalenia wzajemnych relacji między tymi pojęciami. Nie wdając się w szczegóły, gdyż nie to jest przedmiotem niniejszego opracowania, wspomnieć tylko wypada, że w literaturze z zakresu prawa karnego bardzo mocno akcentowane jest, że obowiązujący kodeks karny wykonawczy ${ }^{6}$ posługuje się pojęciem „resocjalizacja” w sposób nad wyraz „powściągliwy”7. Próżno szukać tego terminu w treści art. 67 § 1 k.k.w. traktującym o celach wykonywania kary pozbawienia wolności, jak też w rozdziale XI: Wykonywanie dozoru, warunkowego umorzenia postępowania i warunkowego zawieszenia wykonania kary, w którym do za-

${ }^{3}$ W. Ambrozik, Proces readaptacji spotecznej i jego istota, [w:] Resocjalizacja. Teoria i praktyka pedagogiczna, t. 2, red. B. Urban, J.M. Stanik, Warszawa 2007, s. 182.

${ }^{4} \mathrm{~K}$. Biel, Determinanty readaptacji spolecznej $w$ narracjach bytych skazanych Centrum Integracji „Pro domo” w Krakowie, „Studia Paedagogica Ignatiana” 2018, nr 1, s. 161.

5 A. Fidelus, Determinanty readaptacji społecznej skazanych, Warszawa 2012, s. 19.

${ }^{6}$ Ustawa z dnia 6 czerwca 1997 roku — Kodeks karny wykonawczy (tekst jedn. Dz.U. z 2020 r. poz. 523, dalej: k.k.w.).

7 Zob. B. Stańdo-Kawecka, O koncepcji resocjalizacji w polskiej literaturze naukowej polemicznie, „Probacja” 2010, nr 1, s. 109. 
dań podmiotów wykonujących tego rodzaju orzeczenia sądu należy między innymi ,pomoc w readaptacji społecznej skazanego”. Taki stan jest przede wszystkim wynikiem rezygnacji przez ustawodawcę z przymusowej resocjalizacji skazanych na karę pozbawienia wolności — na rzecz poszanowania ich praw i wolności ${ }^{8}$, jak też wątpliwości co do efektów oddziaływań resocjalizacyjnych w zakładach karnych. Niemniej jednak, jak słusznie zauważa B. Stańdo-Kawecka ${ }^{9}$, termin „resocjalizacja” nadal używany jest w literaturze naukowej z zakresu pedagogiki oraz prawa karnego wykonawczego, na przykład w ustawach pozakodeksowych i aktach wykonawczych ${ }^{10}$.

Mając to na względzie, stwierdzić należy, że termin „resocjalizacja” jest związany z procesem wykonywania kary pozbawienia wolności, w warunkach izolacji, termin zaś ,readaptacja” — z oddziaływaniem na skazanego na wolności, to jest po odbyciu kary pozbawienia wolności, ewentualnie po opuszczeniu zakładu karnego w wyniku zastosowania instytucji warunkowego przedterminowego zwolnienia z odbycia reszty kary pozbawienia wolności. Termin ten odnosi się także do oddziaływania na skazanych za pomocą tak zwanych środków wolnościowych, to jest środków prawnokarnej reakcji na przestępstwo niezwiązanych z pozbawieniem wolności, ale raczej z oddziaływaniem na skazanych w ramach tak zwanej wolności kontrolowanej. Pod tym pojęciem kryją się środki związane z poddaniem sprawcy próbie, w szczególności warunkowe zawieszenie wykonania kary oraz kara ograniczenia wolności, która także ma cechy instytucji probacyjnej.

8 Zob. też T. Kalisz, A. Kwieciński, Cele izolacji penitencjarnej w perspektywie odrzucenia idei przymusowej resocjalizacji, „Przegląd Prawa i Administracji” 2013, nr 90 , s. 118 n.

9 B. Stańdo-Kawecka, op. cit., s. 111.

10 Por. art. 2 ust. 2 pkt 1 ustawy z dnia 9 kwietnia 2010 roku o służbie więziennej (tekst jedn. Dz.U z 2020 r. poz. 848); art. 1 ustawy z dnia 27 lipca 2001 roku o kuratorach sądowych (tekst jedn. Dz.U. z 2020 r. poz. 167); zob. też R. Tadla, Resocjalizacja skazanych - zarys problematyki, „Probacja” 2015, nr 1, s. 125-134; A. Jaworska, Prewencja recydywy przestęczej - innowacje w resocjalizacji penitencjarnej, „Probacja” 2010, nr 1, s. 21-35; S. Woronicz, Resocjalizacja - zarys problematyki, [w:] Resocjalizacja - zarys problematyki. Opracowania tematyczne, Kancelaria Senatu — Biuro Analiz i Dokumentacji, Warszawa 2015, s. 3-15. 
W tym kontekście „readaptacja społeczna” oznaczać będzie raczej konieczność wyeliminowania dysfunkcji, które istnieją i są powodem popełnienia przestępstwa, w celu nabycia umiejętności funkcjonowania w społeczeństwie bez wchodzenia w konflikt z prawem niż powrót do funkcjonowania w społeczeństwie po pewnym okresie izolacji. Dotyczyć zatem będzie osób, które w procesie socjalizacji nie wykształciły zdolności adaptacyjnych bądź te zdolności utraciły, ale z innych powodów niż okres izolacji penitencjarnej.

Pozostaje jeszcze wyjaśnienie terminu ,system” readaptacji społecznej. Według definicji encyklopedycznej ,system” to: ,zespół wzajemnie sprzężonych elementów, spełniający określoną funkcję i traktowany jako wyodrębniony z otoczenia w określonym celu [...]"11. Na tej podstawie należy wnioskować, że system readaptacji społecznej to zespół wyodrębnionych i wzajemnie powiązanych elementów, których celem jest ułatwienie lub umożliwienie skazanemu ponownego przystosowania się do życia w społeczeństwie bez wchodzenia w konflikt z prawem. W ramach systemu readaptacji społecznej wyróżnić można następujące elementy:

— podmiot podlegający readaptacji (beneficjent) — skazany,

- grupa podmiotów świadczących profesjonalną pomoc w readaptacji, ale także kontrolujących ten proces - kurator sądowy, pracownik socjalny oraz inne organizacje świadczące taką pomoc,

- podmioty mogące służyć pomocą (nieprofesjonalną) — na przykład rodzina, środowisko, podmiot docelowych działań — społeczeństwo,

- środki do realizacji celu — środki wolnościowe,

— metody służące realizacji celu — ustalane przez poszczególne podmioty (profesjonalne i nieprofesjonalne) zgodnie z ich kompetencjami i wiedzą.

W całym procesie konieczne jest wsparcie profesjonalne na przykład podmiotu wykonującego środek wolnościowy orzeczony przez sąd, którym jest kurator sądowy, oraz ścisła współpraca z innymi podmiotami działającymi w ramach systemu ${ }^{12}$.

11 Encyklopedia PWN, www.encyklopedia.pwn.pl (dostęp: 1.03.2020).

12 Zob. M. Gawęcka, Resocjalizacja w środowisku otwartym. Koincydencja probacji i pracy socjalnej, „Probacja” 2009, nr 3-4, s. 56 n. 
Realizacja zaś celu następuje na trzech poziomach:

1. zmiana dotycząca samego skazanego (osiąganie celu przez nauczanie, potęgowanie zdolności rozwiązywania problemów, naukę wiary w siebie - readaptacja do potrzeb środowiska);

2. zmiana w relacji skazany-środowisko (umiejętność wpływania na rzeczywistość);

3. zmiana odnośnie do środowiska (włączenie do systemu pomocy, mobilizowanie do samodzielnego czynnego udziału w życiu społecznym) ${ }^{13}$.

Na każdym z wymienionych poziomów istotną rolę odgrywają tak zwane determinanty readaptacji społecznej, czyli czynniki, które warunkują skuteczną readaptację $e^{14}$. Mają one charakter zarówno indywidualny (na przykład poczucie własnej wartości, odpowiednia motywacja do zmiany zachowania), jak i społeczny (na przykład kontakty z rodziną czy też najbliższym otoczeniem) $)^{15}$.

\section{II}

Warto tu postawić pytanie o miejsce i rolę, jaką odgrywają środki wolnościowe w systemie readaptacji społecznej. Jak już wspomniano w pierwszej części opracowania, warunkowe zawieszenie wykonania kary należy do instytucji związanych z poddaniem sprawcy próbie ${ }^{16}$. Kara ograniczenia wolności natomiast zawiera w sobie elementy probacyjne, co przejawia się na przykład w możliwości nałożenia na skazanego na tę karę, obowiązków probacyjnych ${ }^{17}$. Na tej podstawie zasadne jest twierdzenie, że wymienione środki wolnościowe zajmują bardzo ważne miejsce wśród środków reakcji karnej. Są one też elementem szeroko pojętej probacji. W literaturze przedmiotu terminem tym obejmuje się ,„proces [...], w którym osoba poddana próbie, zgodnie z warunkami nałożonymi przez sąd, umotywowana przez kuratora sądowego współuczestniczy w oparciu o po-

13 Ibidem.

14 K. Biel, op. cit., s. 162.

15 Ibidem.

16 Zob. rozdział VIII ustawy z dnia 6 czerwca 1997 roku - Kodeks karny (tekst jedn. z dnia 20 lipca 2018 r., Dz.U. 2018 poz. 1600, ze zm., dalej: k.k.).

17 Por. art. $34 \S 3$ k.k. 
moc środowiskową (naturalne, otwarte środowisko jej życia) w kreowaniu własnej tożsamości zintegrowanej wewnętrznie i ze społeczeństwem"18.

Probacja w szerokim znaczeniu obejmuje zatem takie obszary działalności, jak: pomoc (opieka) społeczna, kontrola społeczna oraz zmiana społeczna ${ }^{19}$. Są to jednocześnie elementy niezbędne w procesie readaptacji, o czym był już mowa.

Jeśli zaś chodzi o rolę środków wolnościowych w systemie readaptacji społecznej, to z materialnoprawnego punktu widzenia może ona zostać wyznaczona na podstawie pewnych kryteriów wyodrębnionych w ramach trzech grup:

1. normatywny kształt instytucji (określony w k.k.) — pozwala na określenie możliwości, jakie daje ustawodawca w zakresie wykorzystania danego środka wolnościowego w readaptacji społecznej i wskazanie ewentualnych ograniczeń stąd wynikających;

2. możliwości podmiotu wykonującego środek wolnościowy (orzeczenie sądu) — w tym wypadku kuratora sądowego (wynikają z przepisów k.k.w.) i obejmują między innymi:

- normatywny kształt uprawnień i obowiązków podmiotu wykonującego środek,

- możliwości współpracy z innymi podmiotami w procesie readaptacji (wynikają z przepisów k.k. i k.k.w.),

— środki i metody stosowane przez podmiot w procesie wykonywania środka wolnościowego — jest to pojęcie pozaprawne, należące do zakresu pedagogiki — dobór właściwych środków i metod oddziaływania na skazanego pozostawiony jest podmiotowi wykonującemu orzeczenie sądu ${ }^{20}$;

3. ograniczenia wynikające z praktyki — rzeczywiste obciążenie kuratora sądowego wykonaniem danego środka wolnościowego.

Pierwsze dwa to kryteria o charakterze jakościowym, natomiast ostatnie to kryterium ilościowe. Mając na względzie rozległą problematykę, ale także ograniczenia wynikające z publikacji niniejszego tekstu, dalsze rozważania zostaną ograniczone do analizy jednego środka wolnościowego, a mianowicie warunkowego zawieszenia wykonania kary.

18 A. Bałandynowicz, Profilaktyka i środki probacyjne w praktyce resocjalizacyjnej, [w:] Resocjalizacja. Teoria i praktyka..., s. 32-36.

19 Zob. M. Gawęcka, op. cit., s. 56.

20 Por. S. Lelental, Kodeks karny wykonawczy. Komentarz, Warszawa 2020, s. 342. 


\section{III}

Pierwszym z kryteriów, według których oceniać możemy rolę omawianego środka w systemie readaptacji społecznej, jest normatywny kształt instytucji określony w k.k. z 1997 roku. Przypomnieć należy, że warunkowe zawieszenie wykonania kary jest instytucją głęboko zakorzenioną w polskim systemie prawa karnego, gdyż została ona wprowadzona już w k.k. z 1932 roku ${ }^{21}$. Normatywny kształt instytucji w obowiązującym kodeksie karnym z 1997 roku należy przedstawić z uwzględnieniem stanu prawnego przed 1 lipca 2015 roku i po tej dacie.

Na wstępie jednak warto podkreślić, że warunkowe zawieszenie wykonania kary jest jedną z trzech instytucji związanych z poddaniem sprawcy próbie, uregulowaną w rozdziale VIII k.k. (art. 69-76 k.k.). Jej istota polega na tym, że sąd po przeprowadzeniu postępowania sądowego, w którym uznaje sprawstwo i winę sprawcy, wymierza karę, przy czym zawiesza jej wykonanie na pewien czas, tak zwany okres próby, określając jednocześnie warunki, jakie sprawca $w$ jego trakcie musi spełnić ${ }^{22}$. Jeśli skazany wywiąże się z nałożonych na niego obowiązków, kara nie jest wykonywana, jeśli zaś nie będzie przestrzegał określonych warunków, sąd zarządza (lub może zarządzić) wykonanie orzeczonej wcześniej kary.

W pierwotnej wersji k.k. z 1997 roku omawiana instytucja miała zastosowanie do trzech rodzajów kar, a mianowicie: kary grzywny, pod warunkiem że została orzeczona jako kara samoistna, kary ograniczenia wolności oraz kary pozbawienia wolności (art. $69 \S 1$ k.k.). W praktyce jednak udział dwóch pierwszych wymienionych kar w ogólnej liczbie kar, których wykonanie warunkowo zawieszono, wynosił mniej niż $1 \%{ }^{23}$. Warunkowe zawieszenie wykonania kary pozbawienia wolności możliwe było po spełnieniu następujących przesłanek (art. $69 \S 1$ k.k.): sąd wymierzył karę nieprzekraczającą 2 lat pozbawienia wolności (przesłanka formalna) i w przekonaniu sądu było to wystarczające do osiągnięcia wobec

21 Więcej na ten temat zob. na przykład J. Skupiński, Warunkowe zawieszenie wykonania kary, [w:] System Prawa Karnego, t. 6. Kary i inne środki reakcji prawnokarnej, red. M. Melezini, Warszawa 2016, s. 1096-1114.

22 Zob. M. Leonieni, Warunkowe zawieszenie wykonania kary w polskim prawie karnym, Warszawa 1974, s. 174.

23 Wynika to z danych za lata 1999-2006, J. Skupiński, op. cit., s. 1116. 
skazanego celów kary, w szczególności zapobieżenia ponownemu popełnieniu przestępstwa (przesłanka materialna - pozytywna prognoza kryminologiczna). Owo przekonanie sądu kształtowane było na podstawie kryteriów wskazanych w treści art. 69 § 2 k.k., to jest postawy sprawcy, właściwości, warunków osobistych, dotychczasowego sposobu życia oraz zachowania po popełnieniu przestępstwa.

Ustawodawca przewidział jednak pewne ograniczenia o charakterze podmiotowym. Co do zasady warunkowego zawieszenia wykonania kary pozbawienia wolności nie można było bowiem stosować wobec multirecydywistów, chyba że sąd uznał, że zachodzi ,wyjątkowy wypadek uzasadniony szczególnymi okolicznościami” — art. 69 § 3 k.k. Po 1 lipca 2010 roku $^{24}$ zastosowanie warunkowego zawieszenia wykonania kary pozbawienia wolności, także wobec sprawcy występku o charakterze chuligańskim oraz sprawcy określonego w art. 178a $§ 4$ k.k., możliwe było tylko w szczególnie uzasadnionych wypadkach. Jednocześnie ustawodawca rozszerzył możliwość warunkowego zawieszenia wykonania kary, wprowadzając szczególną podstawę zawieszenia kary wobec sprawcy, który współdziałał z innymi osobami w popełnieniu przestępstwa, a który ujawni wobec organu ścigania informacje dotyczące osób uczestniczących w popełnieniu przestępstwa oraz okoliczności jego popełnienia, a także wobec sprawcy, który niezależnie od wyjaśnień złożonych w swojej sprawie ujawni i przedstawi organowi ścigania istotne okoliczności popełnienia innego przestępstwa zagrożonego karą powyżej 5 lat pozbawienia wolności (art. 60 § 3 i 4 k.k. — tak zwany mały świadek koronny).

Jak wspomniano, najważniejszym elementem instytucji warunkowego zawieszenia wykonania kary był okres próby. Wynosił on od 2 do 5 lat w przypadku warunkowego zawieszenia kary pozbawienia wolności, chyba że dotyczył sprawcy młodocianego bądź recydywisty — wówczas wynosił od 3 do 5 lat oraz od 1 roku do 3 lat w przypadku warunkowego zawieszenia wykonania pozostałych kar (art. 70 § i 2 k.k.) i biegł od momentu uprawomocnienia się orzeczenia. Wyjątkiem był okres próby orzekany wobec tak zwanego małego świadka koronnego. Wówczas nie znajdował zastosowania art. 69 § 1 k.k., co pozwalało sądowi warunko-

24 Wówczas weszła w życie ustawa z dnia 12 lutego 2010 roku nowelizująca k.k. (Dz.U. Nr 40, poz. 227). 
wo zawiesić karę pozbawienia wolności do lat 5 na okres próby wynoszący do 10 lat. W tym czasie skazany był zobowiązany spełnić warunki ustanowione przez sąd.

W kontekście zarówno realizacji funkcji prewencyjnej, jak i readaptacji społecznej skazanego okres ten miał ogromne znaczenie. Przede wszystkim w okresie próby sąd mógł nałożyć na skazanego obowiązki, których katalog został określony w art. 72 § 1 i 2 k.k. ${ }^{25}$ Należą do nich: obowiązek informowania sądu lub kuratora o przebiegu okresu próby, przeproszenia pokrzywdzonego, wykonywania ciążącego na sprawcy obowiązku łożenia na utrzymanie innej osoby, wykonywania pracy, nauki lub przygotowania do zawodu, powstrzymywania się od nadużywania alkoholu lub używania innych środków odurzających, poddania się leczeniu, w szczególności odwykowemu lub rehabilitacyjnemu albo oddziaływaniom terapeutycznym, uczestnictwa w oddziaływaniach korekcyjno-edukacyjnych, powstrzymania się od przebywania w określonych środowiskach lub miejscach, powstrzymania się od kontaktowania się z pokrzywdzonym lub innymi osobami w określony sposób lub zbliżania się do pokrzywdzonego lub innych osób, opuszczenia lokalu zajmowanego wspólnie z pokrzywdzonym, innego stosownego postępowania w okresie próby, jeżeli może to zapobiec ponownemu popełnieniu przestępstwa.

Ponadto sąd mógł zobowiązać skazanego do naprawienia szkody w całości lub w części albo do uiszczenia świadczenia pieniężnego. Alternatywnie mógł także orzec odpowiedni środek karny ${ }^{26}$. Godne uwagi jest, że sąd mógł orzec jeden lub kilka obowiązków albo nie orzec żadnego z nich. Decyzja sądu uzależniona była przede wszystkim od rodzaju dysfunkcji, która miała zostać wyeliminowana w wyniku oddziaływania na skazanego w okresie próby. Ponadto sąd mógł nałożyć na skazanego grzywnę (art. 71 k.k.) oraz poddać go dozorowi kuratora sądowego albo innego podmiotu wskazanego w treści art. 73 § 1 k.k. Ustawodawca wprowadził obowiązkowy dozór wyłącznie wobec skazanych młodocianych, którzy dopuścili się czynu umyślnego, oraz multirecydywistów. W póź-

25 Katalog ten był modyfikowany, między innymi na podstawie ustawy z dnia 27 lipca 2005 roku (Dz.U. Nr 163, poz. 1363) oraz ustawy z dnia 10 czerwca 2010 roku (Dz.U. Nr 125, poz. 842).

26 Zob. B. Myrna, Instytucja warunkowego zawieszenia wykonania kary w'świetle kodyfikacji karnej z 1997 r., „Nowa Kodyfikacja Prawa Karnego” 7, 2001, s. 34. 
niejszym okresie obowiązkowym dozorem objęto także sprawców przestępstw popełnionych w związku z zaburzeniami preferencji seksualnych.

Podsumowując — należy podkreślić, że okres próby mógł przybrać jedną z trzech form: tak zwane proste warunkowe zawieszenie, to jest bez nałożonych obowiązków i bez dozoru, warunkowe zawieszenie połączone z co najmniej jednym obowiązkiem, ale bez dozoru, warunkowe zawieszenie $\mathrm{z}$ co najmniej jednym obowiązkiem i dozorem.

Mając na względzie, że okres próby jest dynamiczny, a celem jest oddziaływanie na skazanego w warunkach wolnościowych, do osiągnięcia jego poprawy ustawodawca przewidział możliwość modyfikacji obowiązków w okresie próby, skutkujących między innymi nałożeniem nowych obowiązków albo zwolnieniem z dotychczasowych (art. 74 k.k.).

Ustawodawca przewidział także różne sposoby zakończenia okresu próby. Zakładając, że sprawca w określonym przez sąd czasie będzie przestrzegał porządku prawnego i wywiązywał się z nałożonych obowiązków, to po upływie 6 miesięcy od zakończenia okresu próby skazanie zostanie zatarte. Jeśli natomiast w okresie próby skazany nie przestrzega porządku prawnego, narusza warunki ustalone przez sąd, to w zależności od stopnia naruszenia sąd może albo nawet musi zarządzić wykonanie zawieszonej kary. Obligatoryjnie sąd zarządza wykonanie kary pozbawienia wolności w trzech przypadkach: gdy skazany w okresie próby popełnił podobne przestępstwo umyślne, za które orzeczono prawomocnie karę pozbawienia wolności ${ }^{27}$, jeśli skazany za przestępstwo popełnione z użyciem przemocy lub groźby bezprawnej wobec osoby najbliższej lub innej małoletniej, zamieszkujących wspólnie ze sprawcą, rażąco narusza porządek prawny, ponownie używając przemocy lub groźby bezprawnej wobec wspomnianych osób ${ }^{28}$, oraz gdy w okresie próby rażąco naruszył porządek prawny, popełniając inne przestępstwo niż wskazane wyżej, ale wcześniej został pisemnie upomniany przez zawodowego kuratora sądowego ${ }^{29}$. Fakultatywnie sąd może zarządzić wykonanie kary pozbawienia wolności, jeśli

27 Zob. treść art. 75 § 1 k.k.

28 Art. 75 § 1a dodany kolejną nowelizacją na podstawie ustawy z dnia 10 czerwca 2010 roku.

29 Jest to obligatoryjność względna, gdyż uprzednie upomnienie przez kuratora skutkuje obligatoryjnym zarządzeniem wykonania kary w razie braku reakcji po stronie skazanego, o ile nie przemawiają przeciwko takiej decyzji szczególne względy (art. 75 
skazany w okresie próby rażąco narusza porządek prawny, zwłaszcza popełnił przestępstwo niebędące przestępstwem umyślnym i podobnym do poprzedniego lub za które nie orzeczono prawomocnie kary pozbawienia wolności - w przypadku braku upomnienia kuratora, a także wtedy, gdy skazany po wydaniu wyroku, ale przed jego uprawomocnieniem się rażąco narusza porządek prawny, zwłaszcza gdy popełnił wówczas przestępstwo (art. 75 § 1 i 2 k.k.).

Nową jakość instytucji warunkowego zawieszenia wykonania kary nadała ustawa z dnia 20 lutego 2015 roku o zmianie ustawy — Kodeks karny oraz niektórych innych ustaw ${ }^{30}$, która zaczęła obowiązywać od dnia 1 lipca 2015 roku. Do najważniejszych zmian z pewnością zaliczyć należy ograniczenie możliwości stosowania warunkowego zawieszenia wykonania kary wyłącznie do kary pozbawienia wolności. Jest to wyraz uwzględnienia wysuwanych w literaturze przedmiotu postulatów zniesienia warunkowego zawieszenia wykonania kar niezwiązanych z pozbawieniem wolności ${ }^{31}$. Kolejną istotną zmianą w materialnoprawnym kształcie instytucji jest odmienne ukształtowanie przesłanek formalnych. Zgodnie z aktualną treścią art. 69 § 1 k.k. sąd może warunkowo zawiesić wykonanie kary pozbawienia wolności nieprzekraczającej roku, o ile sprawca w czasie popełnienia przestępstwa nie był skazany na karę pozbawienia wolności (także orzeczonej z warunkowym zawieszeniem jej wykonania) ${ }^{32}$. Należy podkreślić, że wprowadzenie owej negatywnej przesłanki ma na celu zabezpieczenie przed multiplikacją kar orzekanych z warunkowym zawieszeniem ich wykonania. Jednak trzeba pamiętać, że „skazanie” obowiązuje od momentu uprawomocnienia się orzeczenia do momentu zatarcia skazania ${ }^{33}$. Przesłanki te nie dotyczą sprawców wskazanych w prze-

§ 2a) - przepis wprowadzony w wyniku nowelizacji dokonanej ustawą z dnia 16 września 2011 roku, która weszła w życie 1 stycznia 2012 roku.

30 Dz.U. z 2015 r. poz. 369.

31 Zob. na przykład W. Zalewski, Krytycznie o zawieszeniu wykonania kary w polskim prawie karnym, [w:] Kary i środki wolnościowe w perspektywie praktyki orzeczniczej $i$ wykonawczej, red. T. Kalisz, „Nowa Kodyfikacja Prawa Karnego” 33, 2014, s. 149.

32 Zob. ibidem, s. 151.

33 Por. art. 107 k.k. W tym zakresie zob. T. Kalisz, Warunkowe zawieszenie wykonania kary w perspektywie zmian wprowadzonych ustawa z dnia 20 lutego 2015 roku o zmianie ustawy - Kodeks karny oraz niektórych innych ustaw, „Nowa Kodyfikacja Prawa Karnego" 37, 2015, s. 143. 
pisach art. 60 § 3 i 4 k.k., którzy nadal korzystają ze szczególnej podstawy orzekania o warunkowym zawieszeniu wykonania kary, określonej w art. $60 \S 5$ k.k. Poza tym obniżona została zarówno dolna, jak i górna granica okresu próby, który teraz wynosi od 1 roku do 3 lat, z wyjątkiem sprawcy młodocianego oraz sprawcy przestępstwa z użyciem przemocy, wobec których granice te wynoszą od 2 do 5 lat.

Kolejną zmianą wartą odnotowania jest konieczność nałożenia przez sąd na sprawcę co najmniej jednego obowiązku próby. Oznacza to, że od 1 lipca 2015 roku nie istnieje już tak zwane proste warunkowe zawieszenie wykonania kary. Może ono zatem zostać orzeczone w dwóch postaciach, a mianowicie: warunkowe zawieszenie wykonania kary pozbawienia wolności połączone z co najmniej jednym obowiązkiem bez dozoru oraz warunkowe zawieszenie wykonania kary połączone z co najmniej jednym obowiązkiem próby oraz z dozorem kuratora sądowego lub osoby godnej zaufania (fakultatywnym albo obligatoryjnym) ${ }^{34}$, przy czym grupa podmiotów, wobec których dozór jest obligatoryjny, się nie zmieniła.

Ostatnia istotna zmiana mająca wpływ na materialnoprawny kształt omawianej instytucji dotyczy przesłanek zarządzenia wykonania kary. Nadal ma ono charakter obligatoryjny bądź fakultatywny. Jednak podstawę tego pierwszego tworzy popełnienie przez skazanego podobnego przestępstwa umyślnego, za które orzeczono prawomocnie karę pozbawienia wolności, ale wyłącznie orzeczoną bez warunkowego zawieszenia wykonania kary ${ }^{35}$. Pozostałe przesłanki pozostały bez zmian. Jako absolutne novum ustawodawca wprowadził rozwiązanie, uregulowane w treści art. 75a k.k., polegające na odmiennym niż dotychczas określeniu skutków rażącego naruszenia porządku prawnego. Zgodnie z treścią § 1 art.

34 Zob. art. 73 § 1 k.k.; w zakresie omawianych zmian zob. też M. Niewiadomska-Krawczyk, Warunkowe zawieszenie wykonania kary po nowelizacji k.k. i k.k.w. - z perspektywy zadań kuratora sądowego, „Nowa Kodyfikacja Prawa Karnego" 36, 2015, s. 126 n.

$35 \mathrm{~W}$ pierwotnym brzmieniu przepisu art. $75 \S 1 \mathrm{k} . \mathrm{k}$. dotyczyło to także prawomocnego orzeczenia kary pozbawienia wolności z warunkowym zawieszeniem jej wykonania, ale zgodnie z wyrokiem TK z dnia 17 lipca 2013 roku w tej części przepis ten został uznany za niezgodny z konstytucją; zob. T. Kalisz, Obligatoryjne zarzadzenie wykonania kary warunkowo zawieszonej. Uwagi na tle wyroku Trybunału Konstytucyjnego z 17 lipca 2013 r. oraz uchwały Sądu Najwyższego z 27 marca 2014 r., „Nowa Kodyfikacja Prawa Karnego" 33, 2014, s. 71-88. 
75a k.k. sąd, zarządzając wykonanie kary wobec sprawcy, co do którego istnieje podstawa do fakultatywnego jej zarządzenia, może, zamiast zarządzenia wykonania pierwotnie orzeczonej kary pozbawienia wolności, zamienić ją na karę ograniczenia wolności orzekaną w formie obowiązku pracy albo na grzywnę, stosując podany w treści przepisu przelicznik. Przed podjęciem decyzji sąd jednak powinien rozważyć, czy jest to zasadne ze względu na realizację celów kary, zważywszy na ciężar gatunkowy popełnionego przestępstwa oraz jego rodzaj. Takie rozwiązanie budzi wątpliwości chociażby dlatego, że niewywiązanie się przez sprawcę z warunków zawieszenia kary nie przynosi negatywnych konsekwencji, ale wręcz ,premiuje” skazanego przez wykonanie kary łagodniejszego rodzaju niż kara orzeczona pierwotnie.

Po omówieniu normatywnego kształtu instytucji warunkowego zawieszenia wykonania kary należy rozważyć, jakie są możliwości bądź ograniczenia podmiotu wykonującego omawiany środek wolnościowy, co wskaże jego rolę w readaptacji skazanego.

Na wstępie należy podkreślić, że orzeczenia z warunkowym zawieszeniem wykonania kary wykonywane są przez zawodowych kuratorów sądowych, będących organami postępowania wykonawczego, przy czym pewne czynności w tym postępowaniu, na przykład niektóre dozory, mogą być wykonywane przez kuratorów społecznych jako czynności powierzone.

Zakres praw i obowiązków kuratorów związanych z wykonywaniem tego typu orzeczeń określony jest w rozdziale XI k.k.w.: Prawa i obowiązki kuratora sądowego, wykonywanie dozoru, warunkowego umorzenia postępowania i warunkowego zawieszenia wykonania kary. Działania podejmowane przez kuratorów sądowych regulują przepisy art. 173 i 174 k.k.w. Wynika z nich, że podstawowym zadaniem kuratora zawodowego, poza czynnościami stricte technicznymi polegającymi na nawiązaniu kontaktu ze skazanym poddanym dozorowi lub wobec którego orzeczono obowiązki próby ${ }^{36}$, jest organizacja i prowadzenie działań mających na celu pomoc skazanemu w społecznej readaptacji, zapobieżenie jego powrotowi do przestępstwa, a także działań kontrolujących przestrzeganie przez skazanego nałożonych obowiązków ustanowionych przez sąd

36 Por. art. 169 k.k.w. i art. 172 k.k.w. 
i związanych z dozorem ${ }^{37}$. Z tego wynika bardzo doniosła rola kuratora sądowego w wykonywaniu tego typu orzeczeń, polegająca na prowadzeniu oddziaływań na skazanego w warunkach wolnościowych, które nie tylko mają charakter kontrolny, lecz także mają przeciwdziałać ponownemu popełnieniu przestępstwa. Ponadto mają one pomóc skazanemu w społecznej readaptacji. Choć przepis ten zawiera bardzo ogólne sformułowania, to można na jego podstawie wyprowadzić wniosek, że zakres oddziaływania na skazanego oraz ingerencji w proces jego readaptacji może być różny. Działania kuratora mogą bowiem sprowadzać się wyłącznie do kontroli okresu próby i realizacji nałożonych na sprawcę obowiązków, ale mogą także bardziej ingerować w proces readaptacji skazanego, gdy orzeczony został dozór. Potwierdzeniem tego stanowiska może być analiza treści art. $173 \S 2$ k.k.w., który w sposób bardziej szczegółowy określa zadania zawodowego kuratora sądowego. Wynika z niej, że kurator zawodowy wykonujący orzeczenie $\mathrm{z}$ warunkowym zawieszeniem wykonania kary w szczególności zobowiązany jest do:

- sprawowania dozorów w stosunku do skazanego,

- kontrolowania w okresie próby wykonania przez skazanego nałożonych na niego obowiązków,

- składania wniosków o ustanowienie rozszerzenie lub zmianę obowiązków w okresie próby, o zwolnienie od obowiązków albo oddanie pod dozór lub zwolnienie od dozoru,

— składanie wniosków o zarządzenie wykonania kary, której wykonanie warunkowo zawieszono.

Z tego wynika, że kurator sądowy jest w każdym stadium postępowania wykonawczego. Składanie odpowiednich wniosków wymaga od kuratora stałego kontaktu ze skazanym, zbudowania z nim odpowiednich relacji, poznania zarówno samego skazanego, jak i jego najbliższego otoczenia. Wydaje się, że zwłaszcza sprawowanie dozoru pozwala nie tylko pomóc skazanemu zrozumieć potrzebę przestrzegania porządku prawnego, lecz także jest świetną okazją do oddziaływań readaptacyjnych na skazanego, budowania jego systemu własnej wartości, relacji z najbliższymi, współpracy ze środowiskiem. Pozwala to nie tylko przygotować samego skazanego na powrót do społeczeństwa, lecz także współpra-

37 Zob. art. $173 \S 1$ k.k.w. 
cować na tym polu z instytucjami świadczącymi taką pomoc, z rodziną oraz otoczeniem. Wprawdzie w wymienionym katalogu brakuje konkretnego obowiązku czy uprawnienia kuratora polegającego na współpracy $\mathrm{z}$ innymi podmiotami $\mathrm{w}$ zakresie realizacji orzeczenia o warunkowym zawieszeniu wykonania kary czy konkretnie w sprawowaniu dozoru, to wydaje się, że taka współpraca jest oczywista i wynika z samego zadania, jakim jest wspomniana wcześniej organizacja i prowadzenie działań mających na celu pomoc w społecznej readaptacji skazanego. Ustawodawca nie wskazuje środków ani metod, które kurator sądowy ma prawo czy obowiązek stosować w procesie realizacji orzeczenia sądu. Ich dobór pozostawiony jest kuratorowi i zależy od jego wiedzy i doświadczenia, co też trzeba ocenić pozytywnie.

Można zatem postawić pytanie, czy są jakieś ograniczenia ustawowe lub pozaustawowe, które mogą wpłynąć negatywnie na proces readaptacji skazanego z zastosowaniem omawianego środka wolnościowego. Odpowiedź na to pytanie jest twierdząca. Wydaje się, że pierwsze ograniczenia wynikają z samego kształtu materialnoprawnego instytucji. Paradoksalnie, wprowadzona w 2015 roku przesłanka negatywna zapobiegająca multiplikacji orzeczeń o warunkowym zawieszeniu wykonania kary może negatywnie wpłynąć na omawiany proces. Jeżeli okres próby przebiegnie prawidłowo, nie ma to znaczenia, natomiast jeśli skazany naruszy w okresie próby porządek prawny, to nie można ponownie orzec kary z warunkowym zawieszeniem jej wykonania, a to oznacza, że nie można kontynuować oddziaływania, które może mieć sens nie tyle z punktu widzenia prewencji, ile readaptacji właśnie.

Wydaje się także, że pewnym ograniczeniem w procesie readaptacji skazanego z zastosowaniem omawianego środka może być wprowadzony w przepisie art. 169b k.k.w. w 2015 roku obowiązek szacowania ryzyka powrotu skazanego do przestępstwa. Polega ono na zakwalifikowaniu skazanego poddanego pod dozór do jednej z trzech grup — podstawowej, o zmniejszonym albo o podwyższonym ryzyku powrotu do przestępstwa. Wydaje się, że takie działanie na etapie postępowania wykonawczego może powodować stygmatyzację oraz frustrację skazanego, co nie jest dobrym początkiem procesu readaptacji. Albowiem z jednej strony sąd, orzekając o warunkowym zawieszeniu wykonania kary, daje skazanemu „szansę” na wykazanie, że jest w stanie przestrzegać porządku prawne- 
Tabela 1. Obciążenie dozorami, w tym związanymi z warunkowym zawieszeniem wykonania kary

\begin{tabular}{|c|r|r|r|r|r|r|r|c|}
\hline \multirow{2}{*}{ Rok } & \multicolumn{2}{|c|}{$\begin{array}{l}\text { Liczba etatów } \\
\text { kuratorów dla } \\
\text { dorosłych }\end{array}$} & \multicolumn{7}{|c|}{ Wykonywanie dozorów } \\
\hline & \multirow{2}{*}{ z. } & s. & \multicolumn{2}{|c|}{ Wpływ spraw w o.s. } & \multicolumn{2}{|c|}{ Zakończone w o.s. } \\
\cline { 4 - 10 } & & ogółem & z. & s. & ogółem & z. & s. \\
\hline 2012 & 3117 & 17149 & 124784 & 56013 & 68771 & 170191 & 68103 & 102088 \\
\hline 2013 & 3119 & 16239 & 144955 & 66376 & 78579 & 138457 & 63171 & 75304 \\
\hline 2014 & 3167 & 15395 & 101143 & - & - & 123367 & - & - \\
\hline 2015 & 3157 & 14216 & 101142 & - & - & 123367 & - & - \\
\hline 2016 & 3144 & 12884 & 70644 & - & - & 105735 & - & - \\
\hline 2017 & 3099 & 10797 & 50854 & - & - & 86409 & - & - \\
\hline 2018 & 3032 & 8615 & 42807 & - & - & 68983 & - & - \\
\hline
\end{tabular}

Źródło: opracowanie na podstawie danych z Ministerstwa Sprawiedliwości — Wydział Statystycznej Informacji Zarządczej w Departamencie Strategii i Funduszy Europejskich.

go, z drugiej zaś owo przypisanie do „właściwej grupy ryzyka” może niweczyć szansę na skuteczną readaptację ${ }^{38}$. Być może korzystniejszym rozwiązaniem byłoby wprowadzenie tego narzędzia już na wcześniejszym etapie postępowania (jurysdykcyjnego) albo też rezygnacja z jego stosowania.

Kolejnym istotnym ograniczeniem roli omawianego środka w readaptacji skazanych może być częsta zmiana przepisów prawa karnego i karnego wykonawczego odnoszących się do tej instytucji. Powoduje ona konieczność wykonywania przez kuratora sądowego orzeczeń sądu wydanych w różnych reżimach prawnych, co rodzi konieczność prowadzenia postępowania wykonawczego także w tych różnych reżimach prawnych. Konieczność pilnowania procedury i przestrzegania przepisów może spowodować, że prawdziwy cel działań i oddziaływań zejdzie na plan dalszy.

Niezależnie jednak od dotychczasowych rozważań wydaje się, że bardzo poważnym zagrożeniem właściwej realizacji omawianego środka wolnościowego, a co za tym idzie skutecznej readaptacji może być nadmierne obciążenie pracą kuratorów sądowych. Należy podkreślić, że sprawo-

38 Więcej na ten temat zob. M. Niewiadomska-Krawczyk, op. cit., s. 128-133. 


\begin{tabular}{|c|c|c|c|c|c|c|c|c|}
\hline \multicolumn{2}{|c|}{ Wykonywanie dozorów } & \multicolumn{6}{|c|}{ Dozory związane z warunkowym zawieszeniem } \\
wykonania kary
\end{tabular}

wanie dozorów w ramach warunkowego zawieszenia wykonania kary, jak również kontrola okresu próby to tylko wycinek zadań zawodowych kuratorów sądowych składających się na rzeczywiste obciążenie pracą.

Do pełnego zobrazowania roli, jaką odgrywać może omawiany środek wolnościowy w społecznej readaptacji skazanego, konieczna jest analiza danych statystycznych odnoszących się do obciążenia kuratorów sądowych wykonywaniem omawianego środka. Analizie poddano dane z lat 2012-2018, a zatem obejmujące okres przed i po nowelizacji wprowadzonej w 2015 roku. Dane statystyczne przedstawia tabela 1.

Trzeba zaznaczyć, że od roku 2014 zmienił się formularz gromadzenia danych i pewne wartości są podawane ogółem, stąd pola zaznaczone jako brak danych. Niemniej jednak na podstawie danych zawartych w tabeli należy stwierdzić, że w latach 2012-2018 liczba etatów zawodowych kuratorów sądowych dla dorosłych utrzymywała się mniej więcej na tym samym poziomie. Sukcesywnie z roku na rok malała liczba kuratorów społecznych. W latach 2012-2015 wpływ spraw dotyczących dozorów wahał się w granicach 100-145 tys. i rozkładał się mniej więcej po równo między kuratorów zawodowych i społecznych. Zważywszy, że liczba etatów kuratorów zawodowych była prawie trzykrotnie niższa niż kuratorów społecznych, to obciążenie kuratorów zawodowych wpływem tego typu 
spraw było bardzo duże. Analizując wpływ spraw związanych z dozorem ogółem oraz wpływ spraw dotyczących dozoru przy warunkowym zawieszeniu wykonania kary, stwierdzić należy, że większą część wpływu tworzyły dozory związane z warunkowym zawieszeniem kary. Od 2016 roku zauważalny jest istotny spadek wpływu spraw związanych z dozorem, w tym z dozorem związanym z warunkowym zawieszeniem wykonania kary. Potwierdza to wyrażoną wcześniej opinię o dużym odsetku dozorów związanych z warunkowym zawieszeniem w ogólnej liczbie spraw odnoszących się do dozoru. Ponadto świadczy o tym, że zmiana kształtu materialnoprawnego omawianej instytucji, w tym głównie zmiana jej przesłanek, spowodowała spadek orzeczeń z warunkowym zawieszeniem wykonania kary. Ponadto stwierdzić należy, że począwszy od 2016 roku, liczba spraw zakończonych w danym okresie sprawozdawczym maleje, choć jest nadal bardzo wysoka i utrzymuje się na poziomie 1,5-2 razy większym niż wpływ tego rodzaju spraw. Podobnie wysoka jest liczba spraw, które pozostały w referacie w ostatnim dniu okresu sprawozdawczego, co oznacza, że mimo zmniejszającego się wpływu tego rodzaju spraw nadal dużo ich pozostaje w referatach poszczególnych kuratorów, zwłaszcza zawodowych.

Podsumowując przedstawione rozważania, należy stwierdzić, że prowadzą one do następujących wniosków. Przede wszystkim środek wolnościowy, jakim jest warunkowe zawieszenie wykonania kary, ma istotne znaczenie w procesie readaptacji skazanych. Świadczy o tym nie tylko normatywny kształt samej instytucji, lecz także stworzone przez ustawodawcę możliwości oddziaływania na skazanego przez podmiot wykonujący orzeczenie. Trzeba jednak podkreślić, że same rozwiązania prawne nie wystarczą do skutecznego osiągnięcia celu. Potrzebne jest zaangażowanie wszystkich podmiotów włączonych w system readaptacji społecznej.

\section{Bibliografia}

Ambrozik W., Proces readaptacji spotecznej i jego istota, [w:] Resocjalizacja. Teoria i praktyka pedagogiczna, red. B. Urban, J.M. Stanik, t. 2, Warszawa 2008.

Bałandynowicz A., Profilaktyka i środki probacyjne w praktyce resocjalizacyjnej, [w:] Resocjalizacja. Teoria i praktyka pedagogiczna, red. B. Urban, J.M. Stanik, t. 2, Warszawa 2008. 
Biel K., Determinanty readaptacji społecznej w narracjach bytych skazanych Centrum Integracji „Pro domo” w Krakowie, „Studia Paedagogica Ignatiana” 2018, nr 1.

Fidelus A., Determinanty readaptacji społecznej skazanych, Warszawa 2012.

Gawęcka M., Resocjalizacja w środowisku otwartym. Koincydencja probacji i pracy socjalnej, „Probacja” 2009, nr 3-4.

Jaworska A., Prewencja recydywy przestepczej - innowacje w resocjalizacji penitencjarnej, „Probacja” 2009, nr 1.

Kalisz T., Obligatoryjne zarządzenie wykonania kary warunkowo zawieszonej. Uwagi na tle wyroku Trybunatu Konstytucyjnego z 17 lipca 2013 r. oraz uchwaty Sadu Najwyższego z 27 marca 2014 r., „Nowa Kodyfikacja Prawa Karnego” 33, 2014.

Kalisz T., Warunkowe zawieszenie wykonania kary w perspektywie zmian wprowadzonych Ustawa z dnia 20 lutego 2015 r. o zmianie ustawy-Kodeks karny oraz niektórych innych ustaw, „Nowa Kodyfikacja Prawa Karnego” 37, 2015.

Kalisz T., Kwieciński A., Cele izolacji penitencjarnej w perspektywie odrzucenia idei przymusowej resocjalizacji, „Przegląd Prawa i Administracji” 2013, nr 90.

Lelental S., Kodeks karny wykonawczy. Komentarz, Warszawa 2020.

Leonieni M., Warunkowe zawieszenie wykonania kary w polskim prawie karnym, Warszawa 1974.

Machel H., Dewiacyjna tożsamość grupowa skazanych a ich readaptacja i reintegracja społeczna, [w:] Tożsamość grupowa dewiantów a ich reintegracja społeczna, red. W. Ambrozik, A. Kieszkowska, Kraków 2012.

Myrna B., Instytucja warunkowego zawieszenia wykonania kary w świetle kodyfikacji karnej z 1997 r., „Nowa Kodyfikacja Prawa Karnego” 7, 2001.

Niewiadomska-Krawczyk M., Warunkowe zawieszenie wykonania kary po nowelizacji kk $i k k w-z$ perspektywy zadań kuratora sądowego, „Nowa Kodyfikacja Prawa Karnego" 36, 2015.

Skupiński J., Warunkowe zawieszenie wykonania kary, [w:] System Prawa Karnego, t. 6. Kary i inne środki reakcji prawnokarnej, red. M. Melezini, Warszawa 2016.

Stańdo-Kawecka B., O koncepcji resocjalizacji w polskiej literaturze naukowej polemicznie, „Probacja” 2010, nr 1.

Tadla R., Resocjalizacja skazanych - zarys problematyki, „Probacja” 2015, nr 1.

Woronicz S., Resocjalizacja - zarys problematyki, [w:] Resocjalizacja-zarys problematyki. Opracowania tematyczne, Warszawa 2015.

Zalewski W., Krytycznie o zawieszeniu wykonania kary w polskim prawie karnym, [w:] Kary i środki wolnościowe w perspektywie praktyki orzeczniczej i wykonawczej, red. T. Kalisz, „Nowa Kodyfikacja Prawa Karnego” 33, 2014.

\section{Akty prawne}

Ustawa z dnia 6 czerwca 1997 roku — Kodeks karny (tekst jedn. Dz.U. z 2018 r. poz. 1600, ze zm.).

Ustawa z dnia 6 czerwca 1997 roku - Kodeks karny wykonawczy (tekst jedn. Dz.U. z 2020 r. poz. 523). 
Ustawa z dnia 27 lipca 2001 roku o kuratorach sądowych (tekst jedn. Dz.U. z 2020 r. poz. 167).

Ustawa z dnia 9 kwietnia 2010 roku o służbie więziennej (tekst jedn. Dz.U z 2020 r. poz. 848).

\section{Netografia}

Encyklopedia PWN, www.encyklopedia.pwn.pl (dostęp: 1.03.2020).

Stownik języka polskiego PWN, www.sjp.pwn.pl (dostęp: 1.03.2020).

\section{Non custodial measures in the system of social readaptation}

\section{Summary}

This article refers to one of the very important issues connected with the system of social readaptation and in particular, the role of non custodial measures within that system. It is focused on the meaning of the term of „readaptation” as well as the concept of a "system". The aim of that article is to find out the place and the role of non custodial measures, especially conditional suspension of the execution of the deprivation of liberty, in the system of social readaptation.

Keywords: social readaptation;system of social readaptation; non custodial measures. 